\title{
Enterprise Resource Planning in a large construction firm: implementation analysis
}

\author{
HANS VOORDIJK ${ }^{*}$, ARJEN VAN LEUVEN ${ }^{2}$ and ALBERTUS LAAN ${ }^{2}$ \\ ${ }^{\prime}$ Twente University, Technology and Management, P.O. Box 217, 7500 AE Enschede, The Netherlands \\ ${ }^{2}$ Balance Eo Result, P.O. Box 2382, 7500 Cf Enschede, The Netherlands
}

Received 10 June 2002; accepted 22 January 2003

\begin{abstract}
In most large Dutch construction firms, Enterprise Resource Planning (ERP) systems have replaced nonintegrated information systems with integrated and maintainable software. The implementation of ERP systems in such firms is a difficult task. So far, ERP implementations have yielded more failures than successes. This study tries to understand the factors that lead to the success or failure of ERP in large construction firms by focusing on the fits between the following pairs of elements in ERP implementations: business and IT strategy, maturity of the IT infrastructure and the strategic role of IT, and the implementation method and organizational change. The premise of this study is that for an ERP implementation to be successful these elements must somehow fit together. Empirical research was conducted through a case study of three ERP implementations in different business units of a Dutch-based construction firm. Implementing different systems within one company is typical of the way large construction firms in the Netherlands have dealt with ERP. The study shows that the success of ERP implementations depends on consistent patterns between: IT strategy and business strategy, IT maturity and the strategic role of IT, and the implementation method and organizational change.
\end{abstract}

Keywords: Enterprise Resource Planning, construction, information technology

\section{Introduction}

In recent years, most of the large construction firms in the Netherlands (firms having more than 1000 employees) have implemented an Enterprise Resource Planning (ERP) system (Dolmans and Lourens, 2001; Department of Economic Affairs, 2002 ). An ERP system may be defined as a packaged business software system that enables a company to manage the efficient and effective use of resources (materials, human resources, finance, etc.) by providing an integrated solution for the organization's information processing needs (Fui-Hoon Nah et al., 2001). ERP systems provide firms with two new and different types of functionality: a transaction processing function, allowing for the integrated management of data throughout the entire company, and a workflow management function controlling the numerous process flows within the company. ERP facilitates the flow of

*Author for correspondence. E-mail: h.voordijk@sms.utwente.nl information between all the processes in an organization. ERP systems can also be an instrument for transforming functional organizations into process-oriented ones. When properly integrated, ERP supports process-oriented businesses effectively (Al-Mashari and Zairi, 2000).

Recently, several practitioners have stated that ERP implementations have so far yielded more failures than successes in large construction firms. A typical ERP implementation in a large construction firm takes between one and three years to complete and costs tens to hundreds of thousands of euros. For these reasons, there is an urgent need to understand the underlying factors that lead to the success or failure of ERP implementations in such firms. This study seeks an understanding of these factors by analysing the fits between the following pairs of elements in ERP implementations: business and IT strategy, maturity of the IT infrastructure and the strategic role of IT, and the implementation method and organizational change. In the theoretical framework, it will be argued that the fit between these elements is an 
important condition for a successful ERP implementation (Drazin and Van de Ven, 1985).

Empirical case study research was conducted using three ERP implementations in different business units of a Dutch-based construction firm. The implementation of different ERP systems within one company is typical of large construction firms in the Netherlands. The data collection methods used in this case study research included both desk and field research (Yin, 1994). Based on the results of this study, factors leading to the success or failure of ERP in a large construction firm are related to concepts in the existing literature on IT and strategy. The paper is structured as follows: the theoretical framework is presented first. Following this, attention is focused on the case study research design. In the subsequent sections, the cases are presented and analysed. Finally, insights from the case studies are combined with the theoretical framework and conclusions drawn.

\section{Thoretical framework}

Following the strategic alignment model of Henderson and Venkatraman (1999), the basic premise of this study is that a successful implementation of IT depends on different effective patterns of logical links, or 'fits', among the following 'domains' of a firm: business strategies, IT strategy, organizational infrastructure and processes, and IT infrastructure and processes. We translated these fits into factors for success or failure of ERP implementation by focusing on the 'fit' between the following pairs of elements:

- the fit (or lack of it) between business strategy and IT strategy;

- the fit between the level of maturity of the IT infrastructure and the strategic role of IT in relation to ERP;

- the fit between the methods used for implementing ERP and the change in organisational processes.

Each ERP implementation can be characterised in terms of these three pairs of elements or 'fits'.

\section{Business and IT strategy}

The extent to which IT strategies are aligned with a firm's strategies varies widely among firms (Earl, 1989; Betts, 1999). These differences reflect the three evolutionary roles that IT plays in firms (Johnston and Carrico, 1988; Grover et al., 1994; Gupta et al., 1997). These differences can also be seen in the role of ERP. A 'traditional' role for ERP would be a supportive one with no integration between ERP and business strategy. An 'evolving' role would reflect a one-way link: ERP supports the strategy but does not influence it. An 'integral' role reflects the integration of ERP and corporate management in order to improve organizational effectiveness. ERP may also contribute to the three generic competitive strategies of Porter (1985): cost leadership, differentiation, and focus. ERP, as part of a cost leadership strategy, aims to achieve the lowest cost of production. In a differentiation strategy, ERP contributes to the development of a unique product or service, and long-term customer relationships. In a focus strategy, the contribution of ERP will be limited to certain segments (in products, in clients, or in geographic markets).

In addition to generic competitive strategies, distinct generic IT strategies can also be identified. The generic IT strategies identified by Parson (1987) represent different approaches to managing IT resources. This strategy typology can also be used to analyse different ERP implementations. The six IT strategies identified by Parson are:

- Free market: users determine their own needs and how to satisfy them. IT specialists compete against outside vendors for users' customers. A firm buys its IT at the lowest possible costs from the software products market.

- Scarce resource: IT resources and expenditure are constrained, and their use determined by resource allocation procedures, such as ROI criteria. Any IT proposal must clearly define expected costs savings.

- Necessary evil: IT is not used unless there is no alternative.

- Centrally planned: a central decision-making unit integrates business needs with IT capabilities from its understanding of the competitive opportunities and requirements of the firm, and the potential of IT for creating or increasing competitive advantage.

- Leading edge: state of the art IT is developed to create new business opportunities.

- Monopoly: an internal IT group is set up as the sole source for meeting IT demands within reasonable costs. An IT development programme is managed by an internal IT group that reviews IT demands in terms of their potential contribution to the business strategy.

Porter's competitive strategies and Parson's IT strategies can be combined into one matrix (see Table 1). In this study, it is initially assumed that the fit between business and IT strategy is an important condition for the success of ERP.

\section{The level of IT maturity, and the strategic role of IT}

Since IT was first introduced into organizations, there has been an ongoing effort to understand the managerial issues associated with the evolution of IT and the 
Table 1 Relationship between generic competitive strategies and generic IT strategies

\begin{tabular}{llll}
\hline & \multicolumn{3}{c}{ Competitive strategies } \\
\cline { 2 - 4 } & Cost leadership & \multicolumn{1}{c}{ Differentiation } & \multicolumn{1}{c}{ Focus } \\
\hline IT strategies & Free market & Centrally planned & Depends on the \\
& Scarce resource & Leading edge & chosen strategy \\
& Necessary evil & Monopoly & \\
\hline
\end{tabular}

organization. The growth curve of Gibson and Nolan (1974) has become a standard, and widely known, model for analysing this computing evolution within organizations. In this study, the Nolan model is used to analyse the level of IT maturity both before and after the implementation of ERP.

The Nolan model offers a framework in which different stages of IT maturity can be discussed. Nolan characterizes each stage in terms of slack and control. The four stages are (Nolan, 1979; Reynolds, 1992):

(1) Initiation: the computer is placed in the organization. Applications are the replacement of existing manual systems (low slack) and are paid for out of a discretionary budget (low control). In this stage, the focus is on functional cost-reduction applications.

(2) Contagion: a period of rapid and controlled growth in the number and kinds of information system applications developed. In order to nurture widespread use of computer applications in the firm, slack is high. Control remains low in order to promote extensive experimentation with applications in multiple functional areas.

(3) Control: top management gains control over information system resources by implementing formal control processes and standards that stifle nearly all new information system projects. Management actions aim to control and reduce slack.
(4) Integration: the use of information resources increases rapidly, providing new benefits and supporting the overall business strategy. The responsibility for operating the systems is transferred to the users. Conventional data processing activities are tightly controlled.

Nolan has modified his curve several times, due to technical developments and a better insight into computer budgeting. The central idea, however, has remained the same and so the focus remains on the four stages detailed earlier. Nolan's approach can be used to indicate the transition from one stage to the other (see Figure 1). After implementing ERP, the level of IT maturity is expected to increase.

An increasing level of IT maturity may result in a changing strategic role for IT. IT can have different strategic roles inside firms, and these can be categorised using the framework of McFarlan and McKenney (1983). This framework contains two criteria. The first is that for some firms the existing IT operations are crucial for survival, for others not. The second criterion is that new IT applications under development are for some firms of great strategic importance for future competitive success, for others not. When the two criteria are integrated into one framework, four roles for IT can be identified (see Table 2). This typology will be used to analyse the changing strategic role of IT within a firm following ERP implementation.

\begin{tabular}{|c|l|}
\hline$G$ & Building the \\
$r$ & applications \\
$o$ & portfolio \\
$w$ & $t$ \\
\cline { 2 - 2 }$h$ & Building the \\
$\mathrm{h}$ & organization \\
\cline { 2 - 2 } $\mathrm{p}$ & \\
$\mathrm{r}$ & Building the dept. \\
$\mathrm{o}$ & management \\
$\mathrm{c}$ & planning and \\
$\mathrm{e}$ & control \\
\cline { 2 - 2 } $\mathrm{s}$ & Developing \\
$\mathrm{s}$ & user \\
$\mathrm{e}$ & awareness \\
$\mathrm{s}$ & \\
\hline
\end{tabular}

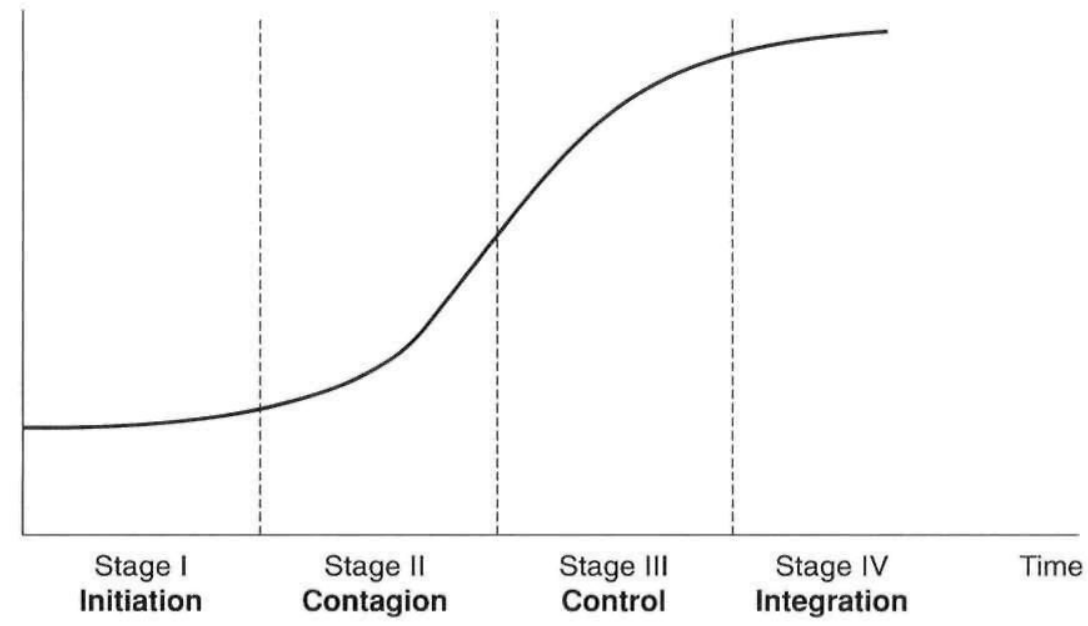

Figure 1 The Nolan growth curve 
Table 2 Existing and future roles of IT systems (McFarlan and McKenney, 1983)

\begin{tabular}{llll}
\hline & & \multicolumn{2}{c}{ Future strategic role of IT } \\
\cline { 3 - 4 } & & Low & High \\
\hline Existing strategic & Low & Support & Turnaround \\
role of IT & High & Factory & Strategic \\
\hline
\end{tabular}

Where IT plays a strategic role, it is essential for executing current strategies and operations, and for future competitive success. The IT strategy, the backbone of such a firm's competitive success, will receive considerable attention from senior management. Where IT plays a turnaround role, a firm is not absolutely dependent on the functioning of the IT to achieve its operating objectives. New IT applications, however, are essential to enable the firm to achieve its strategic objectives. This role fits with the transition of the IT function inside a firm from computer management to information management (from stage three to four on the Nolan curve). If IT plays a turnaround or a strategic role, the IT maturity inside a firm is likely to be high. The IT function has evolved from data-processing into a strategic one (McFarlan et al., 1982; McFarlan and McKenney, 1983).

Where IT plays a factory role, firms are heavily dependent on cost-effective, fully reliable, IT support to enable internal operations to run smoothly. The IT applications under development are, however, not fundamental to a firm's ability to compete in the future. Where IT plays a support role, a firm could continue to operate in the event of a major IT failure. There is no commitment to linking IT to the business strategy. The factory and support strategic IT roles fit with the early stages of the Nolan growth curve: the strategic impact of IT on operations and future strategy is low.

\section{Implementation method and organizational change}

The main differences in IT implementation methods are in their revolutionary or evolutionary nature, and the risk and time needed to implement a system. A 'revolutionary' method requires a fundamental process change. An IT implementation method is labelled evolutionary when no fundamental process changes are required, and only pre-existing processes are automated. Using these criteria, the following strategies can be identified for use in ERP implementation.

In the implementation method known as Business Process Redesign (BPR), IT is used as an agent for strategic change. IT systems enable firms to be more focused on enhancing their customer-service offerings, expanding into new industries, and entering into mergers and acquisitions (Zairi and Sinclair, 1995). BPR leads to fundamental changes in many aspects of the organization (Soliman and Youssef, 1998). In the case of BPR, IT management works closely with corporate management in formulating and implementing an IT enabled or facilitated strategy (for example e-procurement). The through-put time and the risk of failure (i.e. the desired results not being realized) of this revolutionary implementation method are high. Here, implementation is an iterative process, particularly in the design stage: the same steps are repeated several times until the optimal solution is found.

In the method known as As Soon As Possible (ASAP), the implementation time needed is the critical factor. Implementation starts with a predefined model, and the ERP system is adapted to this standard. If processes differ from this standard, they are redesigned. From this perspective, ASAP can be seen as a revolutionary implementation method. When implementation starts, some iterations are possible. The subsequent stages of the implementation process are linear: the process is composed of a series of distinct steps in one sequence.

In the $A S-I S$ method, ERP implementation is aimed at automating existing processes. An important difference to BPR is the evolutionary nature of this method, and the lower risk attached. This implementation method is related to the traditional and supportive orientation of IT towards strategy. IT is not linked to the business strategy. IT primarily serves as a utility (i.e., efficiency and reliability are paramount). The implementation process is linear.

Characteristics of the ERP implementation methods are summarized in Table 3.

As the need for organizational change, and the strategic interest in an ERP implementation, increases, a more iterative implementation model can be expected. In this approach, all the possibilities of an ERP system are thoroughly checked for their potential contribution to the business strategy. Therefore, it is anticipated that companies who are pursuing an integral role for ERP in their business strategy will undertake a more careful analysis of the systems to be implemented.

\section{Case study: research design}

\section{Research approach}

ERP is a relatively new topic for research, and most of its implications have hardly been researched at all (exceptions being Soliman and Youssef (1998), Al-Mashari and Zairi (2000), and Soliman et al. (2001)). As such, an exploratory research approach is considered appropriate and, for this reason, a qualitative case study technique was used for data collection to gain insights into the topic investigated (Yin, 1994). In this case study, three business units of a large Dutch-based construction 
Table 3 Aspects of ERP implementation methods

\begin{tabular}{|c|c|c|c|}
\hline & BPR & ASAP & AS-IS \\
\hline $\begin{array}{l}\text { Involvement of the } \\
\text { management }\end{array}$ & $\begin{array}{l}\text { High: create support for the } \\
\text { system }\end{array}$ & $\begin{array}{l}\text { Middle: convince employees to } \\
\text { use the new system }\end{array}$ & $\begin{array}{l}\text { Low: the system supports } \\
\text { existing rules and } \\
\text { structures }\end{array}$ \\
\hline User participation & $\begin{array}{l}\text { High: particularly in the } \\
\text { design stage }\end{array}$ & $\begin{array}{l}\text { Low: users only evaluate the } \\
\text { new system }\end{array}$ & $\begin{array}{l}\text { Low: users only approve } \\
\text { the software used }\end{array}$ \\
\hline $\begin{array}{l}\text { Training and instruction } \\
\text { intensity }\end{array}$ & $\begin{array}{l}\text { High: learning new processes } \\
\text { and skills }\end{array}$ & Low: learning new skills & Low \\
\hline $\begin{array}{l}\text { Number of implementation } \\
\text { tools used }\end{array}$ & $\begin{array}{l}\text { High: laboratory tests, pilot } \\
\text { projects, prototyping, and } \\
\text { process simulations }\end{array}$ & $\begin{array}{l}\text { Low: predefined models are } \\
\text { used }\end{array}$ & $\begin{array}{l}\text { Low: existing processes } \\
\text { starting point }\end{array}$ \\
\hline Implementation process & $\begin{array}{l}\text { Iterative: particularly in the } \\
\text { design stage }\end{array}$ & $\begin{array}{l}\text { Iterative at the start, subsequent } \\
\text { stages linear }\end{array}$ & Linear \\
\hline Organizational change & High: fundamental changes & Middle & $\begin{array}{l}\text { Low: no changes in } \\
\text { processes or structures }\end{array}$ \\
\hline
\end{tabular}

firm were investigated. These business units implemented ERP in very different business environments. The implementation of different systems within one company is typical of the way large construction firms in the Netherlands have dealt with ERP. By focusing on different business environments, it is possible to analyse the different patterns of logical links between: business and IT strategies, the level of IT maturity and the strategic role of IT, and the implementation methods and organizational change.

\section{Case study design}

The selection of the case study company was theorydriven, rather than on the basis of statistical or random sampling. Armed with the 'ex ante constructs', as Eisenhardt (1989) calls them, we wanted to see if there were different patterns of logical links between ERP and the IT and business strategy, the level of IT maturity and the strategic role of IT, and the implementation method and organizational change. Therefore, a construction firm was selected since it was known to be operating under different conditions in various sectors of the construction industry.

This case firm is one of the leading construction firms in the Netherlands, and appears here under the fictitious name of VL Construction Group. Its activities are divided into four clusters: infrastructure, construction, consultancy and engineering, and trade and industry. The case study focuses on the infrastructure cluster. This part of the firm we call VL Infrastructure and it is a major player in the field of infrastructure in the Netherlands. VL Infrastructure is an integrated provider of civil engineering works, maintenance, and services; and on the basis of this experience is also active in transport systems. Over 2100 employees work on projects; covering, all aspects from involvement in the design phase to implementation, plus subsequent maintenance. The turnover of VL Infrastructure is $€ 250$ million ( $£ 166$ million). VL Infrastructure is divided into seven autonomous business units that work closely together. The multiple case study focuses on the following three business units: Projects, Services, and Equipment.

The Projects unit focuses on large-scale construction and renovation infrastructure projects. This business unit has 400 employees and a turnover of $€ 90$ million ( $£ 60$ million). In this business unit, the most important business functions are calculation, purchasing, and project control. The major cost categories are personnel (35\%), equipment $(15 \%)$, and materials $(50 \%)$.

The Services business unit has 1200 employees and a turnover of about $€ 100$ million ( $£ 66$ million). Its major service product is the maintenance and repair of civil infrastructure and related installations. In this business unit, the most important business functions are maintenance management, activity planning, and engineering. The major cost category is personnel $(80 \%)$. Other costs cover equipment $(10 \%)$ and materials $(10 \%)$.

The Equipment unit has 200 employees and a turnover of $€ 23$ million ( $£ 15$ million). It is responsible for supplying equipment to the other business units inside VL Infrastructure. This business unit also supplies equipment to Dutch competitors of VL Infrastructure. Other activities include the maintenance and development of equipment for other business units and third parties. The most important business functions are resource planning, maintenance planning, logistics, and inventory control. As in Services, the major cost categories are personnel $(80 \%)$, equipment $(10 \%)$, and materials $(10 \%)$.

\section{ERP systems analysed}

Two types of ERP system have been implemented in the business units. Services implemented Baan ERP, a 
product from the Baan Company. Projects and Equipment implemented Metacom 6. Metacom 6 is an ERP system supplied by a Dutch niche player. This niche player dominates, with SAP and Baan, the ERP market in the Dutch construction sector. Modules included in the Metacom system follow the different stages of a building project: acquisition, calculation, purchasing, planning of the project and resources, and financial administration. Baan ERP has the following three basic modules: purchasing, logistics, and services.

Both systems qualify as ERP systems when applying the definition of Markus and Tanis (2000):

- Both ERP systems are commercial packages: that is, they are purchased from software vendors rather than developed in-house from scratch.

- The systems are built to support generic business processes that differ from the way the units analysed do business.

- The systems integrate the software, not the computing platform on which it runs.

- The integration depends on 'configuring' (setting up) the system in particular ways. Configuration means certain modules are installed.

- ERP systems are rapidly changing architecturally and in terms of functionality. Baan and Metacom are pursuing a strategy of componentization, consisting of an open 'backbone' to which the offerings of other vendors can be connected. Both vendors are releasing extensions to their core products designed to handle 'front office' (i.e. sales management), 'supply chain' (i.e. advanced planning and scheduling), data warehousing, and other functions.

\section{Data collection}

The main approaches used for data collection were semi-structured interviews, observations, and documents related to ERP implementations. In each business unit, managers were interviewed who were knowledgeable about both the ERP system itself and its implementation process: senior managers in the business unit including the IT manager, the project manager(s) of the ERP implementation, and core users. The interview questions concerned the business and IT strategy, the level of IT maturity, and different aspects of the implementation method.

In analysing the business and IT strategy, a processoriented assessment of IT business value was followed (see Tallon et al., 2000). This process-oriented approach also provided information on the strategic role of IT in the business units analysed. Following this approach, the focus in the interviews was on the contribution of ERP: to process planning and support (improving internal co-ordination and management decision-making), to the operations of the firm (enhancing operational flexibility, improving labour productivity, enhancing utilization of equipment), to product and service (reducing time to market for new products/services, enhancing product/ service quality), on supplier relationships (developing closer relationships with suppliers, improved monitoring of the quality of products/services from suppliers). Based on this analysis, the dominant goal of the ERP system emerged. Information about the business strategy was gained by interviewing senior management and analysing the firm's strategy documents. This information was confronted with the IT strategy being followed.

The maturity of the IT infrastructure was analysed by framing interview questions in terms of the benchmarks that characterize the different stages of the Nolan curve. These benchmarks are the information processing technology, data-processing organization and expenditure, IT use, data processing and control, and the organization's portfolio of applications (Wiseman, 1985; Sabherwal and Kirs, 1994). By determining where a business unit fits on the various benchmark scales, before and after the ERP implementation, Nolan's approach could be used to indicate the transition from one stage to another. This information was confronted with data on the strategic role of IT inside the business unit, based on the process-oriented approach mentioned above.

The implementations of the different ERP systems were analysed by discussing the items given in the implementation methodologies used by the ERP vendors. Interview questions focused on: the project organization (involvement of senior management, steering and working committees, project management); the training of project members, core users and final users; the analysis of relevant processes to be supported; the role external of consultants; and the implementation tools used. In addition to these aspects of the implementation itself, pre- and post-implementation documents were analysed: implementation proposals, justification for the implementation, test reports, and formal reviews after implementation. The required change in the organization was confronted with the characteristics of the implementation method.

\section{The Projects unit}

\section{Business and IT strategy}

The ERP system was implemented because of the need to replace the existing IT system. Examined more closely, this ERP implementation was not the result of a strategic choice by the management but rather a response to the need to upgrade several outdated systems. External factors (no support for the outdated systems by the 
software supplier, market demand, and millennium bugs in the old software) compelled this business unit to find a new system. The IT strategy used can be characterized as that of a necessary evil. Management reacted to external factors and did not have a strategic focus on state-of-the-art IT solutions. Managerial attention was primarily focused on cost control.

\section{The level of IT maturity and strategic role of IT}

Before implementing the ERP system, the IT maturity of the Projects unit was at stage 2 of the Nolan model with each department using a number of isolated IT applications. The level of IT maturity did not improve after ERP implementation: the firm stayed at stage 2. The ERP system integrated only the software modules of the Calculation and Finance departments. Purchasing ( $40 \%$ of the turnover of this business unit) and overall project planning were not linked with each other through the ERP. This means that delivery schedules would not be adapted following changes in the project planning. Senior management feared a weakening of their negotiating position if purchasing was linked to external suppliers. Since only Calculation and Finance were now linked with each other, this ERP implementation is only the start of a transition from stage 2 to 3 . Further integration and standardization of IT applications is needed to complete this transition. In terms of strategic roles, IT still has a support function. Both before and after ERP implementation, IT was not of strategic importance to the organization.

\section{Implementation method and organizational change}

As mentioned earlier, this ERP implementation was a replacement for an outdated IT system, and as such was a typical example of an AS-IS implementation. In an evolutionary approach, that lasted about two years, the ERP system had to be adapted to existing businesses processes. The implementation focused on supporting the existing processes of the Calculation and Finance departments. It was planned that Purchasing would be the next department to use ERP. The Projects unit wanted to implement the system itself, and hardly any external advisers were hired. Management feared high consultancy costs and the leaking away of sensitive information. This led to a strong intra-company focus. This was also the reason why a supply chain context for the ERP implementation was not developed since such an implementation would require co-ordination with suppliers and customers. The implementation started as a very structured process with regular meetings of the management, the internal project leader, and a small group of core users (representatives of the different departments). Few implementation tools were used, and training and instruction were limited. The process could be characterized as a linear process: software was adapted to existing processes - starting on a general level and ending on a very detailed one. Developing customized software overcame the final obstacles. During implementation, this structured approach became weakened due to time constraints and business schedules.

\section{The Services unit}

\section{Business and IT strategy}

In interviews, managers stated that ERP was needed to increase control and transparency of the processes in the Services unit. With more control and transparency, Services could react faster to changing market demands. Following the liberalization of the market for infrastructure maintenance services, foreign firms have been entering the Dutch market. The ERP implementation was part of the strategic answer to this increasing competition. The IT strategy of this business unit can be characterized as a free market strategy. Services tried to integrate different business functions into one ERP system. The management, however, gave the different departments freedom to buy and use tools other than those provided by the ERP system. The resulting system thus consisted of different IT tools bilaterally linked to the ERP system.

\section{The level of IT maturity and strategic role of IT}

A few years ago, Services could be placed at stage 2 on the Nolan growth curve. Since then, the implementation of ERP has led to substantial integration of localized IT functions. The company has been redesigning its work processes to enable further integration and standardization. As noted, the ERP system is supported by a number of other software tools due to missing functionalities in the ERP system. Baan ERP have supported and integrated the financial aspects of the sales function, the technical maintenance of the infrastructure objects, and the invoice and report function. Strict labour regulations and the irregular working hours of the employees of this business unit partly explain the use of IT tools that are not supported by the ERP system. In particular, purchasing and product quality (measurements of the services delivered) required non-ERP software. The widespread use of IT tools is an aspect of stage 2 of the Nolan model. Implementing an ERP philosophy that integrates these tools into one system reflects the organisation being in transition from stage 2 to stage 3 . The role of IT has changed from support to factory. IT has become much more important in the daily operations of the firm. In the long term, IT may even achieve a strategic position 
where the applications become fundamental to the firm's ability to react to changing market demands.

\section{Implementation method and organizational change}

According to the management, the ERP implementation had to be part of a BPR methodology. In their vision, the BPR would rely heavily on the use of IT to create radically different working methods in order to achieve organizational improvements. Redefining business processes was one of the objectives of this implementation. Several aspects of existing processes were, however, difficult to change (strict labour regulations and irregular working hours). Using the free market IT strategy, the external and internal project managers for this implementation gave much freedom to the core users involved. Management delegated their responsibility to an external project manager, and user participation, training, and instruction intensity were low. Various implementation tools were used. Overall, the approach became a typical example of a linear AS-IS implementation: software tools were adapted to existing processes.

\section{The Equipment unit}

\section{Business and IT strategy}

The Equipment unit followed a centrally planned IT strategy. Senior management chose a centralized approach and, in their view, ERP was a tool that had no direct relationship with the business strategy. The focus was on increasing the efficiency of the planning process. The management compelled the employees to work with only the new system. Importing data from the earlier IT systems (used before the ERP implementation) into the new one was forbidden.

\section{The level of IT maturity and strategic role of IT}

Before implementation, Equipment used three systems that could not exchange information with one another. These different, isolated, applications have been replaced by one ERP system. In order to get all the IT applications included in this system, a tailor-made ERP system was developed by a software firm. The main objective of implementing ERP was to improve the planning, the planning process, and the link between planning and finance. In terms of Nolan, Equipment advanced from stage 2 to stage 3 . IT has been centralized, and current ERP implementation efforts are focused on further integration and standardization. Following implementation, the role of IT had changed from support to factory. The importance of IT increased in the daily operations, but had little impact on future business strategy. ERP was used as an internal tool to increase productivity by improving the planning process.

\section{Implementation method and organizational change}

The implementation method used could be characterized as AS-IS (existing processes were the starting point) with some elements of BPR. The BPR elements included were an iterative implementation method and high user participation. Right from the start of the implementation, core users were involved. These users acted as intermediaries between the departments and the software supplier and they commented on the system prototype on behalf of their departments. Since the old system functioned well, there was much resistance to change. The high level of user participation was an attempt to decrease this resistance. The low level of training and instruction, and the limited use of implementation tools, were typical AS-IS elements.

\section{Discussion}

Using the data from the case studies, the success or failure of the ERP implementations can be explained by analysing the fits between the following pairs of elements: business and IT strategy, the maturity of the IT infrastructure and its strategic role, and the implementation method and organizational change.

\section{Business and IT strategy}

From the case studies, it is concluded that only the necessary evil IT strategy of the Projects unit fits with the actual competitive strategy of this firm: the focus is on cost control (see Table 4, Business and IT strategy column). There appears to be misfits between the free market IT strategy of Services, and the centrally planned IT strategy of Equipment, and their respective competitive strategies. Services wanted to implement ERP in order to react faster to market demands. The business strategy, focusing on differentiation, is not aligned with the IT strategy that fits with cost leadership. In the Equipment unit, the misfit is the other way around. The business strategy focuses on increasing efficiency and lowering costs, while the IT strategy is one that normally focuses on creating new business opportunities. As a result of these misfits, the implementations of integrated enterprise systems were not a success in the Services and Equipment units, and they had to deal with much resistance.

The misfits between the IT and business strategies can be explained by the dominance of cost strategies in the construction industry. Of the cases analysed, only Services had the option of following a non-cost strategy 
Table 4 The case study results

\begin{tabular}{|c|c|c|c|}
\hline Cases & Business and IT strategy & $\begin{array}{l}\text { IT maturity and the } \\
\text { strategic role of IT }\end{array}$ & $\begin{array}{l}\text { Implementation method } \\
\text { and organizational change }\end{array}$ \\
\hline Projects & $\begin{array}{l}\text { Fit } \\
\text { - Cost control } \\
\text { - Necessary evil }\end{array}$ & $\begin{array}{l}\text { Fit } \\
-\quad \text { Stage } 2 \text { to } 3 \\
-\quad \text { Support }\end{array}$ & $\begin{array}{l}\text { Fit } \\
-\quad \text { AS-IS } \\
-\quad \text { No process change }\end{array}$ \\
\hline Services & $\begin{array}{l}\text { Misfit } \\
\text { - Differentiation strategy } \\
\text { - Free market }\end{array}$ & $\begin{array}{l}\text { Fit } \\
\text { - Stage } 2 \text { to } 3 \\
\text { - From Support to Factory }\end{array}$ & $\begin{array}{l}\text { Misfit } \\
- \text { BPR } \\
- \text { No process change }\end{array}$ \\
\hline Equipment & $\begin{array}{l}\text { Misfit } \\
\text { - Cost control } \\
\text { - Central planning }\end{array}$ & $\begin{array}{l}\text { Fit } \\
\text { - Stage } 2 \text { to } 3 \\
\text { From Support to Factory }\end{array}$ & $\begin{array}{l}\text { Fit } \\
\text { - AS-IS + some BPR elements } \\
\text { Planning process changed }\end{array}$ \\
\hline
\end{tabular}

since this business unit was not so dependent on public bids. Services had longer-term contracts. The dominant strategy of most other contractors is, using Porter's strategy typology, a low-cost one for all segments of the market. This cost-driven nature of the industry makes a fit between a firm, and IT strategies that focus on product or service differentiation, unlikely.

\section{The level of IT maturity and strategic role of IT}

The second element of the analysis focuses on the fit between the level of IT maturity and the strategic role of IT. Employing an ERP philosophy that integrates different IT applications into one system reflects that all the business units are in transition from stage 2 to stage 3 (see Table 4, IT maturity and the strategic role of IT column). Of the three units, Equipment had transformed itself most clearly from stage 2 to stage 3 . In all the cases analysed, the IT does not have a strategic focus. Both before and after ERP implementation, IT was not of strategic importance for Projects. For the Services and Equipment units, IT has become much more important in their daily operations. The position of IT has changed from one of support to one of factory. In all three cases, the strategic IT roles match the early stages of the Nolan growth curve. In these stages, reflecting a relatively low level of IT maturity inside a firm, the strategic impact of IT on operations and future strategy is low. IT may achieve a strategic position for Services in the future. Whether the unit advances from the support to either the factory or the strategic role depends on whether Services continues to roll out new strategic uses for IT. If this happens, the IT maturity will increase substantially.

In all three cases, the ERP implementation focused on the back-office processes of the construction company. The functionalities provided by the ERP system support and integrate traditional back-office functions such as cost control, equipment planning, and calculation. These functions are recurrent and stable, and can therefore be standardized. They are not frustrated by industry characteristics such as the temporary coalitions formed to realize construction projects, location-bound production, and the one-off nature of much of the work. Back-office functions do not, however, have the primary attention of the management. The cases show that ERP is used as an intra-company tool, whereas the primary processes in the construction industry are characterized by inter-company relationships. This explains why ERP does not play a strategic role in the three units analysed, and why IT maturity remains low. Inter-organizational IT tools in the construction industry require a high level of IT maturity and a strategic orientation.

\section{Implementation method and organizational change}

The implementation methods used in the Projects and Equipment business units can be characterized as AS-IS since software tools were adapted to the existing processes. Projects followed this method most clearly. Equipment basically followed an AS-IS approach but included some elements of BPR. Services tried to use a BPR method but, in the end, the implementation turned into a typical example of AS-IS (see Table 4, Implementation method and organisational change column)

Adopting BPR methods seems to be difficult because it necessitates changing areas related to strategy, technology, culture, management systems, human resources, and structure. The focus on technical aspects, at the cost of change management elements, is a major reason for a sub-optimal implementation process. There are two other reasons why AS-IS implementation methods are dominant. First, processes have to become transparent and standardized within firms when implementing ERP. Informal agreements are no longer possible. For this reason, ERP is the source of much resistance inside organizations. Second, construction firms operate such that each department has its own domains of expertise. These professional, organizational, and functional boundaries are rarely crossed. Since ERP requires these boundaries to be crossed, this inflexibility is a major obstacle to radically changing processes and implementing intra-organizational IT. 


\section{Conclusion}

In this study, the factors leading to the success or failure of ERP implementations in the construction industry have been explained by focusing on the fits between the following pairs of elements: business and IT strategy, maturity of the IT infrastructure and the strategic role of IT, and the implementation method and organizational change. From this fit analysis the following can be concluded:

- If the strategies of a firm are of a cost-driven nature then a fit between the business and IT strategies that focus on differentiation of products or services is less likely. When the business strategies of a construction company change from a low-cost strategy for all market segments, to a differentiation strategy for one or a few market segments, the use of ERP and inter-organisational IT tools will be stimulated.

- ERP will play a strategic role within construction firms if they adopt tools for the inter-organizational standardization of primary processes (their frontoffice activities). Inter-organzsational IT tools require a high intra-organizational IT maturity. ERP will not fill a strategic role if IT efforts are aimed at standardizing the back-office functions of a construction firm. In this situation, the IT maturity of a construction firm will remain low.

- When a firm is still on the lower stages of the Nolan curve, one should expect the AS-IS implementation method to be used. During these stages, IT is aimed at automating existing processes and cutting costs. BPR can be anticipated when firms begin to move from stages 2 or 3 to higher levels of computer evolution, since IT is then used as an agent for radical change. ERP is appropriate for firms at the higher stages of the Nolan curve when it can transform the IT function within firms from computer management to information management.

Inter-organizational IT tools require a high intraorganizational IT maturity. It is claimed that the application of the Capability Maturity Model enables firms to increase their IT maturity and thus build an effective IT infrastructure (Parzinger et al., 2001). Another approach for improving IT maturity within firms is the emerging international standard for software process assessment known as ISO 15504, being developed as part of the SPICE framework (Software Process Improvement and Capability dEtermination) (Kuvaja, 1999). SPICE focuses on the assessment of software processes and can be used by organizations for improving the development, operation and evolution, and support of software.
From an inter-organizational perspective, construction organizations have yet to reach the first stage of the Nolan curve. The temporary and multiple nature of the organizational structure (a result of the dominance of cost strategies) impedes a high IT maturity at the project level. Non-technological aspects, such as stable networks and central co-ordination, are essential preconditions for the development of inter-organizational ERP. Once these preconditions are met, opportunities for ERP systems to manage inter-company processes may be realized.

\section{References}

Al-Mashari, M and Zairi, M. (2000) Supply-chain re-engineering using enterprise resource planning (ERP) systems: an analysis of a SAP R/3 implementation case. International fournal of Physical Distribution $\mathcal{F}^{\circ}$ Logistics Management, 30(3/4), 296-313.

Betts, M. (1999) Strategic Management of IT in Construction, Blackwell Science, Oxford.

Department of Economic Affairs (2002) Next Generation Scenario - ICT in Construction, The Hague (in Dutch).

Dolmans, G. and Lourens, E. (2001) ICT in Construction, Economisch Instituut voor de Bouwnijverheid, Amsterdam (in Dutch).

Drazin, R. and Van de Ven, A.H. (1985) Alternative forms of fit in contingency theory. Administrative Science Quarterly, 30(4), 514-39.

Earl, M.J. (1989) Management Strategies for Information Technology, Prentice Hall, Hemel Hempstead.

Earl, M.J. (1992) Experiences in strategic information systems planning. MIS Quarterly, 17(1), 1-24.

Eisenhardt, K.M. (1989) Building theories from case study research. Academy of Management fournal, 14(4), 532-50.

Fui-Hoon Nah, F., Lee-Shang Lau, J. and Kuang, J. (2001) Critical factors for successful implementation of enterprise systems. Business Process Management fournal, 7(3), 285-96.

Gibson, C. and Nolan, R.L. (1974) Managing the four stages of EDP growth. Harvard Business Review, 52(1), 76-88.

Grover, V., Cheon, M. and Teng, J.T.C. (1994) An evaluation of the impact of corporate strategy and the role of information technology on IS functional outsourcing. European fournal of Information Systems, 3(3), 179-90.

Gupta, Y.P., Karimi, J. and Somers, T.M. (1997) Alignment of a firm's competitive strategy and information technology management sophistication: the missing link. IEEE Transactions on Engineering Management, 44(4), 399-413.

Henderson, J.C. and Venkatraman, N. (1999) Strategic alignment: leveraging information technology for transforming organizations. IBM Systems fournal, 38(2\&3), 472-84.

Johnston, H.R. and Carrico, S.R. (1988) Developing capabilities to use information strategically. MIS Quarterly, 12(1), 37-48. 
Kuvaja, P. (1999) BOOTSTRAP 3.0 - A SPICE conformant software process assessment methodology. Software Quality fournal, 8(1), 7-19.

Markus, M.L. and Tanis, C. (2000) The enterprise systems experience: from adoption to success. In R.W. Zmud (ed.) Framing the Domains of IT Research: Glimpsing the Future Through the Past, Pinnaflex Educational Resources, Cincinnati.

McFarlan, F.W. and McKenney, J.L. (1983) Corporate Information Systems Management, Dow Jones-Irwin, Homewood.

McFarlan, F.W., McKenney, J.L. and Pyburn, P. (1982) Information archipelago: gaps and bridges. Harvard Business Review, 61(1), 145-56.

Nolan, R.L. (1979) Managing the crises in data processing. Harvard Business Review, 57(2), 115-26.

Parson, G.L. (1987) Fitting Information Systems Technology to the Corporate Needs: The Linking Strategy, Teaching Note 9-183-176, Harvard Business School.

Parzinger, M.J., Nath, R. and Lemons, M.A. (2001) Examining the effect of the transformational leader on software quality. Software Quality fournal, 9(4), 253-67.

Porter, M.E. (1985) Competitive Advantage, Free Press/Collier Macmillan, New York, London.
Reynolds, G.W. (1992) Information Systerns for Managers, 2nd Edn, West Publishing Company, St. Paul.

Sabherwal, R. and Kirs, R. (1994) The alignment between organizational critical success factors and information technology capability in academic institutions. Decision Science, 25(2), 301-30.

Soliman, F. and Youssef, M. (1998) The role of SAP software in business process re-engineering. International fournal of Operations E Production Management, 18(9/10), 886-985.

Soliman, F., Clegg, S. and Tantoush, T. (2001) Critical success factors for integration of CAD/CAM systems with ERP systems. International fournal of Operations $\mathcal{E}$ Production Management, 21(5/6), 609-29.

Tallon P.P., Kraemer, K.L. and Gurbaxani, V (2000) Executives' perceptions of the business value of information technology-a process-oriented approach. fournal of Management Information Systems, 16(4) 145-73.

Wiseman, C. (1985), Strategy and Computer, Dow Jones-Irwin, Homewood.

Yin, R.K. (1994) Case Study Research: Design and Methods, SAGE-Publications, Newbury Perk/London.

Zairi, M. and Sinclair, D. (1995) Business process re-engineering and process management. Management Decision, 33(3), 3-16. 
Copyright of Construction Management \& Economics is the property of Taylor \& Francis Ltd. The copyright in an individual article may be maintained by the author in certain cases. Content may not be copied or emailed to multiple sites or posted to a listserv without the copyright holder's express written permission. However, users may print, download, or email articles for individual use. 